\title{
Implementation Research and Asian American/Pacific Islander Health
}

Asian/pacific Island Nursing Journal

Volume 1(2): 24-34

(C)Author(s) 2016

http://digitalscholarship.unlv.edu/apin/

\author{
Jenny Hsin-Chun Tsai ${ }^{a}$, Shin-Ping Tu ${ }^{b}$, Nancy A. Perrin ${ }^{c}, \&$ Erica S. Breslau ${ }^{d}$
}

\begin{abstract}
Numerous barriers prevent the translation of research into practice, especially in settings with diverse populations. Nurses are in contact with diverse populations across settings and can be an important influence to further implementation research. This paper describes conceptual approaches and methodological issues pertinent to implementation research and implications for Asian American/Pacific Islander (AAPI) health research. The values of using theory to guide implementation research, levels of theory that are commonly used in interventions, and decisions for theory selection are discussed. In addition, shortcomings of randomized controlled trials, the gold standard for testing efficacy of interventions, and present quasi-experimental designs as a plausible alternative to randomized controlled trials when research is conducted in real-world settings are explored. Also examined were three types of quasi-experimental designs, the unit of analysis, the choice of dependent variables, and measurement issues that influence whether research findings and evidence-based interventions are successfully translated into practice. Practicing nurses who are familiar with the AAPI population, as well as nurse researchers who have expertise in AAPI health can play critical roles in shaping future implementation research to advance AAPI health. Nurses can provide practice-based evidence for refining evidence-supported interventions for diverse, real-world settings and theory-based interventions that are socioculturally appropriate for AAPIs. Interdisciplinary, practicebased research networks that bring multiple agencies, organizations, communities, and academic institutions together can be a mechanism for advancing implementation research for AAPI health.
\end{abstract}

Keywords: translation, evidence-based practice, implementation, theories, methods, Asian American/Pacific Islander health

Although substantial resources are directed toward health research in the United States, the impact of advances revealed in research is constrained by a failure to transfer evidence-based findings to widespread delivery of individual and population-based health care (Agency for Healthcare Research and Quality, 2003; Glasgow, Lichtenstein, \& Marcus, 2003; Kerner, Rimer, \& Emmons, 2005; Meissner et al., 2013; Rabin \& Glasgow, 2015). Yet, within this environment, nurses routinely engage with diverse populations in clinical and community settings and are thus particularly wellpositioned to implement evidence-based practices that contribute to the advancement of implementation research to further this effort. Our aim with this paper is to facilitate the translation of evidence into practice through nursing by mapping out conceptual and methodological issues central to the implementation research landscape. Specifically, we lay out theory as the scaffolding for implementation research and describe alternative study designs that will facilitate implementation research. We conclude with the relevance of these planning elements to Asian American/Pacific Island (AAPI) health research.

\footnotetext{
${ }^{a}$ University of Washington, Seattle, WA, USA

${ }^{b}$ Virginia Commonwealth University, Richmond, VA, USA

${ }^{c}$ Kaiser Permanente Center for Health Research, Portland, OR, USA

${ }^{d}$ Division of Cancer Control and Population Sciences at the National

Cancer Institute, Rockville, MD, USA

Corresponding Author:

Jenny H.-C. Tsai, University of Washington

School of Nursing, Department of Psychosocial and Community

Health, Box 357263

Seattle, WA $98195-7263$ USA

Email: jennyt@u.washington.edu

$\mathrm{Ph}$ : (206) 543-6079
} 


\section{Implementation Research}

Dissemination and implementation (D\&I) research is a growing field of study, in which dissemination is conceptualized as the spread of information and materials associated with evidence-based interventions, programs, and policies from the research setting to the clinical and community settings. Dissemination research examines how innovations spread in society (Bowen et al., 2009). Implementation, on the other hand, is the process of putting efficacious interventions into practice within a specific setting, or the actual spreading of information and materials. Implementation research is the use of scientific methods to promote the adoption and integration of research findings and evidence-based interventions into health care policy and practice to improve the quality (effectiveness, reliability, safety, appropriateness, equity, efficiency) of health care and public health (Eccles et al., 2009). Studies of dissemination and implementation include knowledge synthesis, adaptation (intervention fit, scalability, and sustainability), and dissemination. This dissemination and implementation field recognizes the fallacy of prior assumptions that (1) empirically-supported interventions can be transferred into diverse clinical and community settings without attention to the local context, and that (2) a unidirectional flow of information (e.g., publishing a guideline) is sufficient for achieving practice change (Eccles et al., 2009; Glasgow, Marcus, Bull, \& Wilson, 2004).

\section{Use of Theories to Shape Implementation Research}

Theory provides the basis for judging whether all the necessary elements of a program are in place to inform the intervention, the analysis, and the evaluation (Green \& Kreuter, 2000). To advance implementation research, theories are the cornerstone because they (a) provide a framework for generating testable hypotheses and integrating empirical evidence, (b) inform the choice and design of intervention strategies, (c) promote an understanding of why the uptake of an intervention is slower than might be expected, (d) identify how the intervention causes change so that weak links in the causal chain can be identified and strengthened, (e) specify key factors influencing behavior and behavior change, (f) enhance the exploration of mediating mechanisms and potential moderators, and $(\mathrm{g})$ indicate which variables to measure during evaluations (Davies, Walker, \& Grimshaw, 2010; Eccles, Grimshaw, Walker, Johnston, \& Pitts, 2005; Hack, Ruether, Weir, Grenier, \& Degner, 2011; Rothman, 2009).

\section{Theory Selection}

Ferlie and Shortell (2001) identified four levels at which interventions operate: (a) individual-level, (b) interpersonal, (c) organizational, and (d) system-level (Table 1). Each offers a different perspective for intervention design. Individual-level theories focus on knowledge, beliefs, attitudes, self-concept, selfefficacy, intention, norms, skills, and behaviors that characterize an individual enmeshed in a complex system of influences that ultimately shape health behaviors (Crosby, Kegler, \& DiClemente, 2002; Rimer \& Glanz, 2005; Rothman, 2009).

Interpersonal-level theories are applicable for groups or teams and provide insight into social interactions, including dyadic dynamics, friendship, social networks, social support, and relational culture (Pasick et al., 2009). These theories assume individuals exist within and are influenced through interactions with complex social influences that augment the necessary support to bring about behavior change (Rimer \& Glanz, 2005).

Organization-level theories provide explanations of individuals within larger aggregates such as primary care practices, hospitals, health maintenance organizations, or community agencies (Anhang Price, Zapka, Edwards, \& Taplin, 2010; Yano et al., 2011). Assessing health care outcomes across multiple contexts requires an organizational framework that considers policies, practices, and cultures that affect implementation, extends sustainability, and promotes dissemination to other settings (Damschroder et al., 2009; Rothman, Erlich, \& Teresa, 1999). Organizational theories explain the relationships, experiences, or processes that occur within an organizational context.

System-level theories apply to the multiple levels of influences on human behavior and health outcomes that emanate from the social environment (McLeroy, Bibeau, Steckler, \& Glanz, 1988). Conceptually, the social ecological perspective addresses determinants at many levels, including the intrapersonal, interpersonal, organizational, community, and policy, and as such, targets multiple levels rather than determinants at only one level (Weiner, Lewis, Clauser, \& Stitzenberg, 2011). While implementation research offers a range of theories addressing change, guidance is limited as to how to conduct implementation research across multiple levels (Taplin, 2011). Table 1 summarizes the focus, key constructs, and limitations of theory level as well as relevant applications for implementation research (Eccles et al., 2005). 
Tsai et al.: Implementation Research

Table 1. Major Theories and Conceptual Frameworks for Implementation Research

\begin{tabular}{|c|c|c|c|c|}
\hline Level/Theory & Theory Focus & Key Constructs & Limitations & $\begin{array}{l}\text { Applicable for } \\
\text { Implementation }\end{array}$ \\
\hline \multicolumn{5}{|l|}{ Individual Level } \\
\hline $\begin{array}{l}\text { Health Belief } \\
\text { Model (Janz \& } \\
\text { Becker, 1984; } \\
\text { Rosenstock, } \\
\text { Strecher, \& } \\
\text { Becker, 1994) }\end{array}$ & $\begin{array}{l}\text { Prediction of health- } \\
\text { related behaviors } \\
\text { based on individual } \\
\text { attitudes and beliefs. }\end{array}$ & $\begin{array}{l}\text { Perceived threat } \\
\text { - Perceived } \\
\text { susceptibility } \\
\text { - Perceived severity } \\
\text { Perceived benefits } \\
\text { Perceived barriers } \\
\text { Cues to action }\end{array}$ & $\begin{array}{l}\text { Does not incorporate social } \\
\text { norms, peer influence, or } \\
\text { environmental factors that } \\
\text { influence behavior. } \\
\text { Does not capture causal } \\
\text { explanation of behaviors. }\end{array}$ & $\begin{array}{l}\text { Perceived susceptibility } \\
\text { and severity applied to } \\
\text { understand cancer } \\
\text { screening tests: detection } \\
\text { vs. prevention. }\end{array}$ \\
\hline $\begin{array}{l}\text { Stages of Change } \\
\text { Model } \\
\text { (Prochaska, } \\
\text { DiClemente, \& } \\
\text { Norcross, 1992) }\end{array}$ & $\begin{array}{l}\text { Individual decision } \\
\text { making to identify } \\
\text { emotions, cognitions, } \\
\text { and behaviors for a } \\
\text { linear, multi-staged } \\
\text { process of change } \\
\text { from precontemplation } \\
\text { to preparation for } \\
\text { action. }\end{array}$ & $\begin{array}{l}\text { Precontemplation } \\
\text { Contemplation } \\
\text { Action } \\
\text { Maintenance } \\
\text { Preparation for action }\end{array}$ & $\begin{array}{l}\text { Does not consider structural } \\
\text { and environmental factors that } \\
\text { influence an individual's } \\
\text { ability to enact behavior } \\
\text { change. }\end{array}$ & $\begin{array}{l}\text { Useful design for } \\
\text { intervention programs; } \\
\text { captures the processes of } \\
\text { change (e.g., adopting } \\
\text { the intervention). }\end{array}$ \\
\hline $\begin{array}{l}\text { Theory of } \\
\text { Planned Behavior } \\
\text { (Ajzen, 1991; } \\
\text { Ajzen \& Driver, } \\
\text { 1991; Werner, } \\
\text { 2004) }\end{array}$ & $\begin{array}{l}\text { Change in behavior } \\
\text { requires change in } \\
\text { underlying beliefs, } \\
\text { norms, and/or actual } \\
\text { behavioral control. }\end{array}$ & $\begin{array}{l}\text { Behavioral intention } \\
\text { Attitude } \\
\text { Subjective norms } \\
\text { Perceived behavioral } \\
\text { control }\end{array}$ & $\begin{array}{l}\text { Assumes that behavior is the } \\
\text { result of a linear decision } \\
\text { making process and does not } \\
\text { consider that behavior can } \\
\text { change over time. }\end{array}$ & $\begin{array}{l}\text { Social influences used to } \\
\text { endorse or engage an } \\
\text { individual in a behavior } \\
\text { by example of others } \\
\text { (e.g., family, friends) } \\
\text { engaging in the behavior. }\end{array}$ \\
\hline \multicolumn{5}{|c|}{ Interpersonal Level: Social Support Theories } \\
\hline $\begin{array}{l}\text { Social Cognitive } \\
\text { Theory (Bandura, } \\
1988,2015)\end{array}$ & $\begin{array}{l}\text { Interaction of } \\
\text { individual cognitions } \\
\text { and behavior, exerted } \\
\text { through self-efficacy. }\end{array}$ & $\begin{array}{l}\text { Reciprocal } \\
\text { determinism } \\
\text { Behavioral capability } \\
\text { Expectations } \\
\text { Self-efficacy } \\
\text { Observational learning } \\
\text { Reinforcement }\end{array}$ & $\begin{array}{l}\text { Different aspects of the theory } \\
\text { may not be linked. For } \\
\text { example, not all social } \\
\text { learning can be directly } \\
\text { observed. Social Cognitive } \\
\text { Theory does not explain how } \\
\text { social cognition, behavior, } \\
\text { environment, and personality } \\
\text { are related. }\end{array}$ & $\begin{array}{l}\text { Explains learning } \\
\text { through observation, } \\
\text { expectation, and } \\
\text { reinforcement within } \\
\text { social environment. } \\
\text { Providers can model } \\
\text { desirable behavior or use } \\
\text { videotape example of } \\
\text { behavior to facilitate } \\
\text { learning. }\end{array}$ \\
\hline $\begin{array}{l}\text { Social Network } \\
\text { Theory (Barnes, } \\
\text { 1954; Rogers \& } \\
\text { Kincaid, 1980) }\end{array}$ & $\begin{array}{l}\text { Influence of social } \\
\text { relational structures } \\
\text { for persons, groups, or } \\
\text { organizations affects } \\
\text { beliefs and behaviors. }\end{array}$ & $\begin{array}{l}\text { Connectedness } \\
\text { Integration } \\
\text { Diversity } \\
\text { Openness }\end{array}$ & $\begin{array}{l}\text { Levels of analysis include } \\
\text { individual, group, and } \\
\text { network where the attributes } \\
\text { of individuals are less } \\
\text { important than their } \\
\text { relationships and ties with } \\
\text { other actors within the } \\
\text { network. } \\
\text { While the approach is useful } \\
\text { for explaining many real- } \\
\text { world phenomena associated } \\
\text { with networks, it has limited } \\
\text { applicability for interventions } \\
\text { that focus solely on the } \\
\text { individual, or people with no } \\
\text { relations to other people. }\end{array}$ & $\begin{array}{l}\text { Approach is focused on } \\
\text { relations between and } \\
\text { within social units } \\
\text { (individuals, groups, or } \\
\text { organizations) instead of } \\
\text { the properties of these } \\
\text { units themselves. The } \\
\text { properties of } \\
\text { communication networks } \\
\text { generate information on } \\
\text { connectedness, } \\
\text { integration, diversity, } \\
\text { and openness. }\end{array}$ \\
\hline
\end{tabular}




\begin{tabular}{|c|c|c|c|c|}
\hline \multicolumn{5}{|c|}{ Organization Level } \\
\hline $\begin{array}{l}\text { Chronic Care } \\
\text { Model (Wagner, } \\
1996,1998)\end{array}$ & $\begin{array}{l}\text { Effective outpatient } \\
\text { chronic illness care is } \\
\text { characterized by } \\
\text { productive interactions } \\
\text { between active } \\
\text { patients and a prepared } \\
\text { practice team. }\end{array}$ & $\begin{array}{l}\text { Self-management } \\
\text { support } \\
\text { Delivery system design } \\
\text { Decision support } \\
\text { Clinical information } \\
\text { system } \\
\text { Health care } \\
\text { organization } \\
\text { Community }\end{array}$ & $\begin{array}{l}\text { Lack of consideration for } \\
\text { cost-effectiveness. Most } \\
\text { published experience pertains } \\
\text { to larger practice } \\
\text { organizations. Needs to } \\
\text { characterize practice } \\
\text { characteristics predictive of } \\
\text { success. }\end{array}$ & $\begin{array}{l}\text { Integrative framework } \\
\text { guides ambulatory } \\
\text { practice care delivery } \\
\text { through integrated } \\
\text { practice changes to } \\
\text { improve patient care. }\end{array}$ \\
\hline $\begin{array}{l}\text { Consolidated } \\
\text { Framework for } \\
\text { Implementation } \\
\text { Research (CFIR) } \\
\text { (Damschroder et } \\
\text { al., 2009; } \\
\text { Damschroder \& } \\
\text { Hagedorn, 2011) }\end{array}$ & $\begin{array}{l}\text { The CFIR unifies and } \\
\text { consolidates the array } \\
\text { of constructs that } \\
\text { influence } \\
\text { implementation from } \\
\text { the perspective of } \\
\text { models used in } \\
\text { intervention studies. }\end{array}$ & $\begin{array}{l}\text { Intervention } \\
\text { characteristics } \\
\text { Outer setting } \\
\text { Inner setting } \\
\text { Individuals involved } \\
\text { Implementation } \\
\text { process }\end{array}$ & $\begin{array}{l}\text { Does not address how to adapt } \\
\text { the constructs in order to } \\
\text { increase likelihood of } \\
\text { effective implementation. }\end{array}$ & $\begin{array}{l}\text { Useful in helping to } \\
\text { determine whether an } \\
\text { intervention can be } \\
\text { feasibly implemented in } \\
\text { different situations. }\end{array}$ \\
\hline $\begin{array}{l}\text { Systems Model of } \\
\text { Clinical } \\
\text { Preventive Care } \\
\text { (Walsh \& } \\
\text { McPhee, 1992) }\end{array}$ & $\begin{array}{l}\text { Focus: patient- } \\
\text { physician interaction. } \\
\text { Details factors } \\
\text { impinging on each that } \\
\text { promote or inhibit } \\
\text { completion of } \\
\text { preventive care } \\
\text { activities. }\end{array}$ & $\begin{array}{l}\text { Outcomes } \\
\text { Predisposing factors } \\
\text { Enabling factors } \\
\text { Reinforcing factors } \\
\text { Organizational factors } \\
\text { Preventive activity } \\
\text { factors } \\
\text { Situational factors }\end{array}$ & $\begin{array}{l}\text { Does not describe the time } \\
\text { course for receipt of a given } \\
\text { preventive activity. Factors } \\
\text { are not weighted-unable to } \\
\text { distinguish importance of } \\
\text { different factors in different } \\
\text { activities. }\end{array}$ & $\begin{array}{l}\text { Broadly applicable to } \\
\text { counseling and } \\
\text { screening. }\end{array}$ \\
\hline \multicolumn{5}{|l|}{ System Level } \\
\hline $\begin{array}{l}\text { Contingency } \\
\text { Theory (Fiedler, } \\
\text { 1967; Scott, } \\
\text { 1998; Woodward, } \\
\text { 1958) }\end{array}$ & $\begin{array}{l}\text { How individuals and } \\
\text { groups gain power, } \\
\text { access to resources, } \\
\text { and control over their } \\
\text { lives through } \\
\text { collective action. } \\
\text { Leadership must be } \\
\text { fluid and adaptive in } \\
\text { response to } \\
\text { environment. }\end{array}$ & $\begin{array}{l}\text { Adaptation to } \\
\text { environment } \\
\text { Alignment in } \\
\text { management }\end{array}$ & $\begin{array}{l}\text { Fails to address why certain } \\
\text { leadership styles are more } \\
\text { effective in particular } \\
\text { situations than others. Fails to } \\
\text { address what organizations } \\
\text { should do when a leadership- } \\
\text { workplace mismatch occurs. }\end{array}$ & $\begin{array}{l}\text { Useful in macro practice } \\
\text { and for administering } \\
\text { programs by assessing } \\
\text { internal and external } \\
\text { resources to make } \\
\text { structural and process } \\
\text { decisions within an } \\
\text { organization. }\end{array}$ \\
\hline $\begin{array}{l}\text { Social Ecological } \\
\text { Model or Social } \\
\text { Ecological } \\
\text { Perspective } \\
\text { (Green \& } \\
\text { Kreuter, 2005; } \\
\text { McLeroy et al., } \\
\text { 1988; Stokols, } \\
\text { 1996) }\end{array}$ & $\begin{array}{l}\text { Examines the multiple } \\
\text { effects and interactions } \\
\text { between social } \\
\text { elements in an } \\
\text { environment, } \\
\text { including how people } \\
\text { interact with their } \\
\text { environment and the } \\
\text { influence they have on } \\
\text { one another. }\end{array}$ & $\begin{array}{l}\text { Microsystems } \\
\text { Mesosystems } \\
\text { Exosystems } \\
\text { Macrosystems }\end{array}$ & $\begin{array}{l}\text { Provides sequencing of } \\
\text { interventions but no } \\
\text { theoretical indication of which } \\
\text { interventions are likely to } \\
\text { work together in mutually } \\
\text { reinforcing ways and which } \\
\text { are not. }\end{array}$ & $\begin{array}{l}\text { Comprehensive } \\
\text { framework for } \\
\text { understanding multiple, } \\
\text { interacting determinants } \\
\text { of health based on the } \\
\text { principle that health } \\
\text { results from the complex } \\
\text { interactions of personal } \\
\text { factors and multiple } \\
\text { aspects of the physical } \\
\text { and social environments. }\end{array}$ \\
\hline
\end{tabular}


Tsai et al.: I Implementation Research

\section{Application of Theories}

In health care and public health, moving efficacious interventions into practice has been slow and difficult because of diverse practice environments. Interventions with well-articulated theoretical principles offer insight into disentangling the effects of the intervention from the influence of contextual factors that arise at different stages in a clinical practice (Grol \& Grimshaw, 2003). The challenge in using theory is not so much in identifying and assessing individual variables; rather, it is the capacity to select theory and apply it in practice through implementation (Green \& Kreuter, 2000; Rakowski \& Breslau, 2004). For example, unlike routine cancer screening, which can be initiated by the patient and obtained without the need for a provider's referral, the identification and resolution of an abnormal finding is inextricably tied to a clinical setting, a health care provider, and frequently, a medical organization and health care system (Bastani, Yabroff, Myers, \& Glenn, 2004; Safran, Miller, \& Beckman, 2006). Consequently, it is unlikely that one theory will apply equally to every possible intervention or to each intervention level, and as yet, no integrative theories have been developed to guide the implementation of multi-level interventions (Taplin et al., 2012; Yano et al., 2011).

There is growing evidence that multiplebehavior interventions have the potential for much greater impact on public health than single-behavior interventions because they are able to accommodate the complexity of behaviors (Nigg, Allegrante, \& Ory, 2002). Affecting implementation practice, then, will require a multifaceted approach, incorporating theoretical strategies that include patients, providers, the clinic system, as well as the larger health care organization. More attention to theory-based implementation is needed given the growing interest in developing and applying theory to both understand and intervene on multiple health behaviors and at multiple levels.

\section{Alternative Designs for Implementation Research}

Randomized controlled trials (RCTs), participants are randomly assigned into an intervention or control condition, have long been the gold standard in research. The RCT design is meant to decrease concerns about confounding and improve the ability to make causal inferences. One major challenge to the translation of evidence from RCTs is that effect- iveness studies, which are conducted with fewer constraints than that used in RCTs, still require strong study design that is consonant with clinical or community settings. For example, conducting research in real-world settings may not always provide the luxury of random assignment; participants may not be willing to be randomly assigned or ethical objections may deter withholding an intervention from one of the study groups. Delivery of the intervention may not be easily controlled in the real-world setting the way it can be in an experimental setting (SansonFisher, Bonevski, Green, \& D'Este, 2007). While limitations exist, the benefit of conducting research in the real-world setting increases the ability to generalize study findings to other settings (external validity).

Quasi-experimental designs provide a strong alternative to RCTs when research is conducted in real-world settings (Mark \& Reichardt, 2003; Mercer, DeVinney, Fine, Green, \& Dougherty, 2007; Shadish, Cook, \& Campbell, 2002). This is especially true when systematic approaches are incorporated to identify plausible threats to causal inference, rule out other factors as being responsible for the observed effect, and strengthen reliability or accuracy of the results (internal validity). Several quasi-experimental designs (e.g., regression discontinuity and interrupted time-series designs), when analyzed correctly, can lead to unbiased estimates of the difference between groups (Rubin, 1977).

\section{Regression Discontinuity Design}

In this design, assignment to groups is based on some continuous variable; individuals who exceed a given threshold are assigned to the experimental group and those who do not are assigned to the comparison group. For instance, researchers would like to study a hypertension intervention with AAPI clients at health centers. Figure 1 illustrates an example in which treatment is assigned when blood pressure exceeds 150 and cardiovascular events are observed in both groups. The groups are clearly not equivalent at the pre-test. However, when the data are analyzed, the difference between those receiving and not receiving treatment is estimated, conditioned on the variable used to assign participants to treatment (i.e., blood pressure). If this variable is the sole basis on which participants are assigned to groups, then the analyses provide an unbiased estimate for the group effect (Rubin, 1977) or the difference in cardiovascular events between the groups. 


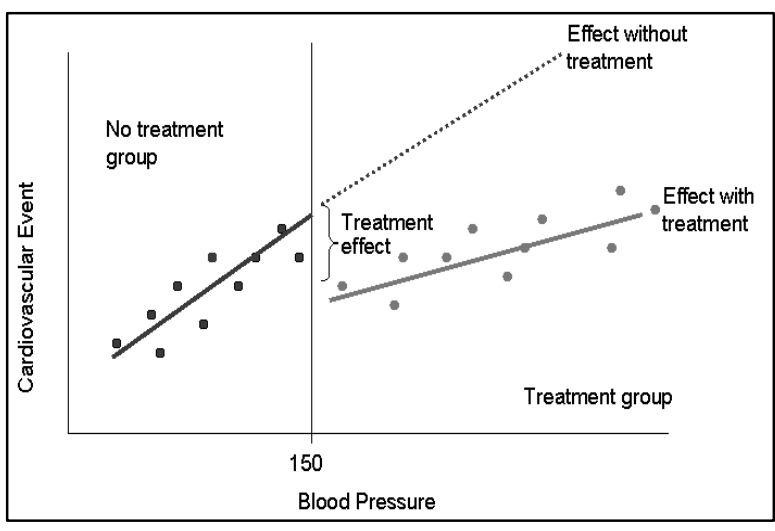

Figure 1. Illustration of a Regression Discontinuity Design

\section{Interrupted Time-series Design}

One particularly useful quasi-experimental design is the interrupted time-series, in which outcomes are followed over time (Biglan, Ary, \& Wagenaar, 2000). At some point during the observation period, an intervention is implemented. Data are collected at regular intervals (e.g., monthly, quarterly) for an extended period before and after the intervention. One advantage of this design is that it allows the researcher to capitalize on historical data that already exist. Smith et al. (2006) examined prescribing error rates in the time period before and after the implementation of an electronic medical record alerting program. Using existing data, prescribing error rates were computed monthly across the entire period. The research team tested whether there was a change between the periods prior to and post-implementation in the level of the error rate, as well as the trend over time in the error rate. Figure 2 illustrates a hypothetical case where there was a decline in the outcome (e.g., prescribing errors) after the intervention was implemented. Segmented regression can be used to test if the level and rate of change over time differs for the time period prior to the intervention and the time period after the intervention (Smith et al., 2006; van Doormaal et al., 2009). The pre-intervention period essentially controls for the level and rate of change in the outcome in the absence of the intervention. As with the regression discontinuity design, the rule by which participants are assigned to intervention versus comparison, which is time in the interrupted timeseries design, is included in the analyses to achieve an unbiased estimate of the effect. The interrupted time-series design has good statistical power if the trend prior to the change is fairly stable. The strengths of this design included an intuitive graphical representation, the ability to use historical data, and the fact that it takes into account the trend prior to the change (West, Biesanz, \& Pitts, 2000).

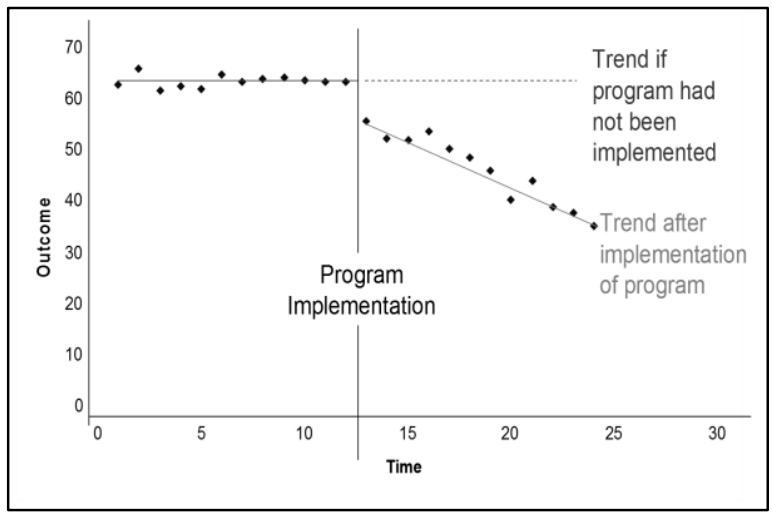

Figure 2. Illustration of an Interrupted Time-series Design

\section{Nonequivalent Control Group Designs}

The nonequivalent control group design is the most commonly used quasi-experimental design (Shadish et al., 2002). While not as strong as the regression discontinuity or the interrupted time-series design, the nonequivalent control group design can be very useful. In this design, preexisting or naturally occurring groups receive different intervention conditions and the groups are compared on the outcome of interest. The groups could be patients treated at different clinics or those treated by different health care teams. For example, researchers who want to study the effect of a new outreach approach to increase colorectal cancer screening in AAPI adults on the West coast might find that some clinics may be using this outreach approach while others are not (Tu et al., 2014). Alternatively, the researcher may be able to implement the outreach program at half the clinics while observing screening rates at all the clinics. The main concern with this design is that intervention conditions may be associated with other confounding factors. Therefore, the main threat to internal validity of this design is that some other difference (not the outreach program in this example) between the naturally occurring groups was responsible for the pattern of results.

\section{Strengthening the Internal Validity of Quasi- experimental Designs}

The major threat to internal validity of the quasiexperimental design was that the outcome may change because of other reasons, such as natural 
Tsai et al.: Implementation Research

history events, differences in rates of maturation, changes in instrumentation, or selection biases (Shadish et al., 2002). The internal validity of quasiexperimental designs can be strengthened by simultaneously examining a different yet similar outcome (over the same time period) that should not be affected by the intervention, or alternatively, by including an additional setting where the intervention did not occur. This allows the researcher to test whether another natural history event changed at the same time as the intended change was implemented, and if this event was responsible for the change in outcomes. For example, Smith et al. (2006) examined changes in prescribing error rates over time for drugs targeted by the intervention to reduce risky prescribing in the elderly. They also followed drugs not targeted by the intervention. Seeing little change in the non-target drugs in comparison to the target drugs strengthened the internal validity of the study.

Another approach to strengthen internal validity is to include multiple baseline periods with staggered implementation points for the intervention as it is unlikely that outside events would occur at the exact time as each of the multiple implementation time points (Hawkins, Sanson-Fisher, Shakeshaft, D'Este, \& Green, 2007). Feldstein et al. (2009) included multiple time periods as well as multiple comparison groups to strengthen the internal validity of their study. They showed that mammogram completion rates improved over time during the implementation of a mammography reminder program, and also improved to an even greater degree after the program was fully implemented. Additionally, the improvement was only seen for those in the targeted age range (50-69 years of age).

Sometimes multiple baselines, staggered implementation, and multiple comparison groups are not possible. Statistical techniques can be used to control confounding of groups. Propensity scores statistically model the differences in participant characteristics, health care utilization, or other variables that may be related to differences between groups. These variables, usually collected prior to or at baseline, are included in a logistic regression to predict if a participant is in the intervention or the comparison group. The probability of being in the intervention group for each participant is then included in the main statistical analyses. This minimizes differences between the groups on the set of variables used in the propensity score and controls for possible confounding of the groups at the onset of the study (Rosenbaum \& Rubin, 1983, 1984; Williamson, Morley, Lucas, \& Carpenter, 2012).

\section{Closing Thoughts: Implications for Asian American/Pacific Islander Health Re- search}

The ultimate goal of implementation research is to "enhance integration of research and practice" (Glasgow \& Emmons, 2007). Nurses, who straddle both practice and research arenas, have an important role in achieving this goal. There is widespread concern over the lack of translation of the results of RCTs into clinical and public health practice (Green, Glasgow, Atkins, \& Stange, 2009; Pasick, Hiatt, \& Paskett, 2004). In fact, clinical practice, public health programs, and health policy all lag in their application of evidence-based knowledge (Tunis, Stryer, \& Clancy, 2003). This gap between evidence and practice is known as the quality chasm (Institute of Medicine Committee on Quality Health Care in America, 2003). Green notes that to have more evidence-based practice, we need more practicebased evidence that comes from implementation in the less controlled "real world" (Green, 2001; Green et al., 2009). Although it may be challenging to conduct research in the less controlled "real world," knowing that interventions can actually work outside of a controlled trial is essential for evidence-based nursing practice, research, and teaching.

Nurses are taught to value RCTs, which focus more on efficacy and less on effectiveness, and to evaluate RCT results and implications. To date, the literature reveals few AAPI studies that use the types of quasi-experimental designs discussed in this paper. Thus, it is appropriate to expand our focus beyond RCTs, and to focus on theories that guide intervention design and on how interventions work in real-world settings and with diverse populations (external validity). This shift in perspective and research methods is critical because of the marked health disparities among AAPI and other ethnic minorities in the United States, and the need for effective, multi-level interventions to eliminate this pervasive societal problem (Keppel, 2007; Rust \& Cooper, 2007).

AAPIs, counting for $5.3 \%$ (16.8 million) of the national population (U.S. Census Bureau, 2013), are the fastest growing ethnic minority group in the United States. The AAPI population consists of people with roots in at least 33 Asian countries and 20 Pacific Islander cultures (U.S. Census Bureau, 2013). Researchers have historically used aggregated data (i.e., AAPI as one category or grouped in the Other category) or excluded AAPI from studies. Federal grants and research projects, as well as publications devoted to AAPI health have expanded 
with recent focus on advancing scientific knowledge and innovation among AAPI populations (Ghosh, 2003; Neta et al., 2015; U.S. Department of Health and Human Services, 2015). However, work remains to foster more minority health research that bridges the gap between research and practice, a role that nurse researchers can promote with practitioners (U.S. Department of Health and Human Services, 2015). Considering the knowledge gap in the literature, practicing nurses who are familiar with diverse AAPI groups are ideally poised to contribute significantly to practice-based evidence. For example, those with cultural and linguistic abilities can advance health equity, improve quality, and promote the adoption, implementation, and evaluation of national standards in health care (U.S. Department of Health and Human Services, 2015). Researchers can then use the new evidence gained from these endeavors to improve the sociocultural relevance of research-tested intervention programs and further evaluate the adoption of modified interventions with targeted AAPI groups in different settings through collaboration, education, and curricular realignment (Stevens, 2013). Nurse researchers with expertise in AAPI health can advance implementation research by using novel research designs and sophisticated quantitative or qualitative analytical approaches. Nurse researchers can also use interdisciplinary efforts when evaluating interventions designed for AAPI health promotion (Chesla, 2008; Sidani, Epstein, \& Moritz, 2003). Nurse researchers can form interdisciplinary, practice-based research networks that promote AAPI health and identify innovative ways to foster the integration of research, clinical, and public health practice for AAPI populations. For instance, the interrupted time-series design described in this paper is well-suited to existing data. Practice-based research networks could collaborate across health care facilities, community-based organizations, voluntary health organizations, public health departments, and academic institutions to compile existing data on AAPI clients and use the interrupted timeseries design to answer new questions about program effectiveness for AAPI health. Practice-based research networks should ensure involving AAPI community agencies and engaging AAPI groups to inform researchers and the networks on how best to frame the research questions, tailor clinical interventions for real-world settings, and interpret results. This process keeps the research connected with the practice and community perspectives. This approach is particularly crucial to AAPI groups that are not commonly included in research because their views then can be integrated throughout the research process. As practice-based research networks work closely with AAPI groups and agencies/organizations to implement efficacious interventions, they can serve as an important force to shape the national discussion about the implementation research agenda for AAPI health.

\section{Acknowledgements}

The authors declared that they did not have any writing assistance.

\section{Declaration of Conflicting Interests}

The authors declared that there is no conflict of interest.

\section{Funding Acknowledgements}

Funding support for this paper was provided by the National Cancer Institute.

\section{References}

Agency for Healthcare Research and Quality. (2003). Diffusion and dissemination of evidence-based cancer control interventions (No. 79). Retrieved from http://archive.ahrq.gov/clinic/epcsums/canconsum.htm

Anhang Price, R., Zapka, J., Edwards, H., \& Taplin, S. H. (2010). Organizational factors and the cancer screening process. Journal of the National Cancer Institute. Monographs, 2010(40), 38-57.

Ajzen, I. (1991). The theory of planned behavior. Organizational Behavior and Human Decision Processes, 50, 179-211.

Ajzen, I., \& Driver, B. L. (1991). Prediction of leisure participation from behavioral, normative, and control beliefs: An application of the theory of planned behavior. Leisure Science, 13, 185-204.

Bandura, A. (1988). Organisational applications of social cognitive theory. Australian Journal of Management, $13,275-302$.

Bandura, A. (2015). On deconstructing commentaries regarding alternative theories of self-regulation. Journal of Management, 41, 1025-1044.

Barnes, J. A. (1954). Class and committees in a Norwegian island parish. Human Relations, 7, 39-58.

Bastani, R., Yabroff, K. R., Myers, R. E., \& Glenn, B. (2004). Interventions to improve follow-up of abnormal findings in cancer screening. Cancer, 101(5 Suppl), 1188-1200.

Biglan, A., Ary, D., \& Wagenaar, A. C. (2000). The value of interrupted time-series experiments for community intervention research. Prevention Science, 1, 31-49.

Bowen, D. J., Sorensen, G., Weiner, B. J., Campbell, M., Emmons, K., \& Melvin, C. (2009). Dissemination 
research in cancer control: Where are we and where should we go? Cancer Causes Control, 20, 473-485.

Chesla, C. A. (2008). Translational research: Essential contributions from interpretive nursing science. Research in Nursing \& Health, 31, 381-390.

Crosby, R. A., Kegler, M. C., \& DiClemente, R. J. (2002). Understanding and applying theory in health promotion practice and research. In R. J. DiClemente, R. A. Crosby, \& M. C. Kegler (Eds.), Emerging theories in health promotion practice and research (1st ed., pp. 1-15). San Francisco: Jossey-Bass.

Damschroder, L. J., Aron, D. C., Keith, R. E., Kirsh, S. R., Alexander, J. A., \& Lowery, J. C. (2009). Fostering implementation of health services research findings into practice: A consolidated framework for advancing implementation science. Implementation Science, 4, 50 .

Damschroder, L. J., \& Hagedorn, H. J. (2011). A guiding framework and approach for implementation research in substance use disorders treatment. Psychology of Addictive Behaviors, 25, 194-205.

Davies, P., Walker, A. E., \& Grimshaw, J. M. (2010). A systematic review of the use of theory in the design of guideline dissemination and implementation strategies and interpretation of the results of rigorous evaluations. Implementation Science, 5, 14.

Eccles, M., Grimshaw, J., Walker, A., Johnston, M., \& Pitts, N. (2005). Changing the behavior of healthcare professionals: The use of theory in promoting the uptake of research findings. Journal of Clinical Epidemiology, 58, 107-112.

Eccles, M. P., Armstrong, D., Baker, R., Cleary, K., Davies, H., Davies, S., . . . Sibbald, B. (2009). An implementation research agenda. Implementation Science, 4, 18.

Feldstein, A. C., Perrin, N., Rosales, A. G., Schneider, J., Rix, M. M., Keels, K., . . . Glasgow, R. E. (2009). Effect of a multimodal reminder program on repeat mammogram screening. American Journal of Preventive Medicine, 37, 94-101.

Ferlie, E. B., \& Shortell, S. M. (2001). Improving the quality of health care in the United Kingdom and the United States: A framework for change. The Milbank Quarterly, 79, 281-315.

Fiedler, F. E. (1967). A theory of leadership effectiveness. New York: McGraw-Hill.

Ghosh, C. (2003). Healthy People 2010 and Asian Americans/Pacific Islanders: Defining a baseline of information. American Journal of Public Health, 93, 2093-2098.

Glasgow, R. E., \& Emmons, K. M. (2007). How can we increase translation of research into practice? Types of evidence needed. Annual Review of Public Health, 28, 413-433.
Glasgow, R. E., Lichtenstein, E., \& Marcus, A. C. (2003). Why don't we see more translation of health promotion research to practice? Rethinking the efficacy-to-effectiveness transition. American Journal of Public Health, 93, 1261-1267.

Glasgow, R. E., Marcus, A. C., Bull, S. S., \& Wilson, K. M. (2004). Disseminating effective cancer screening interventions. Cancer, 101(5 Suppl), 1239-1250.

Green, L. W. (2001). From research to "best practices" in other settings and populations. American Journal of Health Behavior, 25, 165-178.

Green, L. W., Glasgow, R. E., Atkins, D., \& Stange, K. (2009). Making evidence from research more relevant, useful, and actionable in policy, program planning, and practice slips "twixt cup and lip". American Journal of Preventive Medicine, 37(6 Suppl 1), S187191.

Green, L. W., \& Kreuter, M. W. (2000). Commentary on the emerging guide to Community Preventive Services from a health promotion perspective. American Journal of Preventive Medicine, 18(1 Suppl), 7-9.

Green, L. W., \& Kreuter, M. W. (2005). Health program planning: An educational and ecological approach (4th ed.). New York: McGraw-Hill Higher Education.

Grol, R., \& Grimshaw, J. (2003). From best evidence to best practice: Effective implementation of change in patients' care. Lancet, 362, 1225-1230.

Hack, T. F., Ruether, J. D., Weir, L. M., Grenier, D., \& Degner, L. F. (2011). Study protocol: Addressing evidence and context to facilitate transfer and uptake of consultation recording use in oncology: A knowledge translation implementation study. Implementation Science, 6, 20.

Hawkins, N. G., Sanson-Fisher, R. W., Shakeshaft, A., D'Este, C., \& Green, L. W. (2007). The multiple baseline design for evaluating population-based research. American Journal of Preventive Medicine, 33, 162-168.

Institute of Medicine Committee on Quality Health Care in America. (2003). Cross the quality chasm: A new health system for the 21st century. Washington, DC: National Academies Press.

Janz, N. K., \& Becker, M. H. (1984). The Health Belief Model: A decade later. Health Education Quarterly, 11, 1-47.

Keppel, K. G. (2007). Ten largest racial and ethnic health disparities in the United States based on Healthy People 2010 Objectives. American Journal of Epidemiology, 166, 97-103.

Kerner, J., Rimer, B., \& Emmons, K. (2005). Introduction to the special section on dissemination: Dissemination research and research dissemination: How can we close the gap? Health Psychology, 24, 443-446. 
Mark, M. C., \& Reichardt, C. S. (2003). Quasiexperimental and correlational designs: Methods for the real world when random assignment isn't feasible. In C. Sansone, C. C. Morf, \& A. T. Panter (Eds.), The Sage handbook of methods in social psychology (pp. 267-286). Thousand Oaks, CA: Sage.

McLeroy, K. R., Bibeau, D., Steckler, A., \& Glanz, K. (1988). An ecological perspective on health promotion programs. Health Education Quarterly, 15, 351-377.

Meissner, H. I., Glasgow, R. E., Vinson, C. A., Chambers, D., Bronwnson, R. G., Green, L. W., . . Mittman, B. (2013). The U.S. training institute for dissemintation and implementation research in health. Implementation Science, 8, 12.

Mercer, S. L., DeVinney, B. J., Fine, L. J., Green, L. W., \& Dougherty, D. (2007). Study designs for effectiveness and translation research: Identifying trade-offs. American Journal of Preventive Medicine, 33, 139154.

Neta, G., Sanchez, M. A., Chambers, D. A., Phillips, S. M., Leyva, B., Cynkin, L., . . . Vinson, C. (2015). Implementation science in cancer prevention and control: A decade of grant funding by the National Cancer Institute and future directions. Implementation Science, 10, 4.

Nigg, C. R., Allegrante, J. P., \& Ory, M. (2002). Theorycomparison and multiple-behavior research: Common themes advancing health behavior research. Health Education Research, 17, 670-679.

Pasick, R. J., Burke, N. J., Barker, J. C., Joseph, G., Bird, J. A., Otero-Sabogal, R., . . . Guerra, C. (2009). Behavioral theory in a diverse society: Like a compass on Mars. Health Education and Behavior, 36(5 Suppl), 11S-35S.

Pasick, R. J., Hiatt, R. A., \& Paskett, E. D. (2004). Lessons learned from community-based cancer screening intervention research. Cancer, 101(5 Suppl), 11461164.

Prochaska, J. O., DiClemente, C. C., \& Norcross, J. C. (1992). In search of how people change. Applications to addictive behaviors. American Psychology, 47, 1102-1114.

Rabin, B., \& Glasgow, R. E. (2015). An implementation science perspective on psychological science and cancer: What is known and opportunities for research, policy, and practice. American Psychologist, 70, 211220.

Rakowski, W., \& Breslau, E. S. (2004). Perspectives on behavioral and social science research on cancer screening. Cancer, 101(5 Suppl), 1118-1130.

Rimer, B. K., \& Glanz, K. (2005). Theory at a glance: A guide for health promotion practice (2nd ed.). Bethesda: National Cancer Institute.
Rogers, E. M., \& Kincaid, D. L. (1980). Communication networks: Toward a new paradigm for research. New York: Free Press.

Rosenbaum, P. R., \& Rubin, D. B. (1983). The central role of the propensity score in observational studies for causal effects. Biometrika, 70, 41-55.

Rosenbaum, P. R., \& Rubin, D. B. (1984). Reducing bias in observational studies using subclassification on the propensity score. Journal of the American Statistical Association, 79, 516-524.

Rosenstock, I. M., Strecher, V. J., \& Becker, M. H. (1994). The Health Belief Model and HIV risk behavior change. In R. J. DiClemente \& J. L. Peterson (Eds.), Preventing AIDS: Theories and methods of behavioral interventions (1st ed., pp. 5-24). New York: Springer.

Rothman, A. J. (2009). Capitalizing on opportunities to refine health behavior theories. Health Education and Behavior, 36(Suppl 1), 150S-155S; discussion 167S$171 \mathrm{~S}$.

Rothman, J., Erlich, J., \& Teresa, J. G. (1999). Taking action in organizations and communities (2nd ed.). Dubuque: Eddie Bowers Publishing Company.

Rubin, D. B. (1977). Assignment to treatment group on the basis of a covariate. Journal of Educational and Behavioral Statistics, 2, 1-26.

Rust, G., \& Cooper, L. A. (2007). How can practice-based research contribute to the elimination of health disparities? Journal of the American Board of Family Medicine, 20, 105-114.

Safran, D. G., Miller, W., \& Beckman, H. (2006). Organizational dimensions of relationship-centered care. Theory, evidence, and practice. Journal of General Internal Medicine, 21(Suppl 1), S9-15.

Sanson-Fisher, R. W., Bonevski, B., Green, L. W., \& D'Este, C. (2007). Limitations of the randomized controlled trial in evaluating population-based health interventions. American Journal of Preventive Medicine, 33, 155-161.

Scott, W. R. (1998). Organization: Rational natural and open systems (4th ed.). London: Prentice-Hall.

Shadish, W. R., Cook, T. D., \& Campbell, D. T. (2002). Experimental and quasi-experimental designs for generalized causal inference. Boston: Houghton, Mifflin and Company.

Sidani, S., Epstein, D. R., \& Moritz, P. (2003). An alternative paradigm for clinical nursing research: An exemplar. Research in Nursing \& Health, 26, 244255.

Smith, D. H., Perrin, N., Feldstein, A., Yang, X., Kuang, D., Simon, S. R., . . Soumerai, S. B. (2006). The impact of prescribing safety alerts for elderly persons in an electronic medical record: An interrupted time series evaluation. Archives of Internal Medicine, 166, 1098-1104. 
Stevens, K. R. (2013). The impact of evidence-based practice in nursing and the next big ideas. The Online Journal of Issues in Nursing, 18(2), Manuscript 4.

Stokols, D. (1996). Translating social ecological theory into guidelines for community health promotion. American Journal of Health Promotion, 10, 282-298.

Taplin, S. H. (2011, March 4-5). Building the foundation for future research goals. Paper presented at the Multilevel Interventions in Health Care Meeting, Las Vegas, NV. Retrieved from http://www.youtube.com/ playlist?p=PL0126837269E084C5

Taplin, S. H., Anhang Price, R., Edwards, H. M., Foster, M. K., Breslau, E., Chollette, V., . . Zapka, J. (2012). Introduction to the journal supplement: Understanding and influencing multilevel factors across the cancer care continuum. Journal of the National Cancer Institute Monographs, 2012(44), 2-10.

Tu, S.-P., Chun, A., Yasui, Y., Kuniyuki, A., Yip, M.-P., Talyor, V., \& Bastani, R. (2014). Adaptation of an evidence-based intervention to promote colorectal cancer screening: A quasi-experimental study. Implementation Science, 9, 85.

Tunis, S. R., Stryer, D. B., \& Clancy, C. M. (2003). Practical clinical trials: Increasing the value of clinical research for decision making in clinical and health policy. Journal of the American Medical Association, 290, 1624-1632.

U.S. Census Bureau. (2013). Selected characteristics of the native and foreign-born populations: 2013 American Community Survey 1-year estimate. Retrieved from http://factfinder2.census.gov/

U.S. Department of Health and Human Services. (2015). Report to congress on minority health activities as required by the Patient Protection and Affordable Care Act (P. L. 111-148). Washington DC: The U.S. Department of Health and Human Services. Retrieved from http://minorityhealth.hhs.gov/omh/browse.aspx$? \mathrm{lvl}=2 \& l v l i d=57$

van Doormaal, J. E., van den Bemt, P. M., Zaal, R. J., Egberts, A. C., Lenderink, B. W., Kosterink, J. G., . . . Mol, P. G. (2009). The influence that electronic prescribing has on medication errors and preventable adverse drug events: An interrupted time-series study.
Journal of the American Medical Informatics Association, 16, 816-825.

Wagner, E. H. (1996). The promise and performance of HMOs in improving outcomes in older adults. Journal of the American Geriatrics Society, 44, 1251-1257.

Wagner, E. H. (1998). Chronic disease management: What will it take to improve care for chronic illness? Effective Clinical Practice, 1(1), 2-4.

Walsh, J. M. E., \& McPhee, S. J. (1992). A systems model of clinical preventive care: An analysis of factors influencing patient and physician. Health Education Quarterly, 19, 157-175.

Werner, P. (2004). Reasoned action and planned behavior. In S. J. Peterson \& T. S. Bredow (Eds.), Middle range theories: Application to nursing research (pp. 125147). Philadelphia: Lippincott Williams \& Wilkins.

Weiner, B. J., Lewis, M. A., Clauser, S. B., \& Stitzenberg, K. (2011, March 4-5). In search of synergy: Strategies for combining interventions at multiple levels. Paper presented at the Multilevel Interventions in Health Care: Building the Foundations for Future Research, Las Vegas, NV.

West, S. G., Biesanz, J. C., \& Pitts, S. C. (2000). Causal inference and generalization in field settings: Experimental and quasi-experimental designs. In H. T. Reis \& C. M. Judd (Eds.), Handbook of research methods in social and personality psychology. New York: Cambridge University Press.

Williamson, E., Morley, R., Lucas, A., \& Carpenter, J. (2012). Propensity scores: From naive enthusiasm to intuitive understanding. Statistical Methods in Medical Research, 21, 273-293.

Woodward, J. (1958). Management and technology. London: Her Majesty's Stationery Office.

Yano, E., Green, L. W., Glanz, K., Ayanian, J. Z., Mittman, B. S., Chollette, V., \& Rubenstein, L. V. (2011, March 4-5). Implementation and spread of interventions into the multilevel context of routine practice and policy: Implications for the cancer care continuum. Paper presented at the Multilevel Interventions in Health Care: Building the Foundations for Future Research, Las Vegas, NV. 